Abstracta Iranica

Revue bibliographique pour le domaine irano-aryen

Volume 27 | 2006

Comptes rendus des publications de 2004

\title{
«Les Sidoniens à Baniyas ». Transeuphratène, 28 (2004), pp. 143-147.
}

\section{Astrid Nunn}

\section{(2) OpenEdition}

1 Journals

\section{Édition électronique}

URL : http://journals.openedition.org/abstractairanica/5743

DOI : 10.4000/abstractairanica. 5743

ISSN : 1961-960X

Éditeur :

CNRS (UMR 7528 Mondes iraniens et indiens), Éditions de l'IFRI

\section{Édition imprimée}

Date de publication : 15 mai 2006

ISSN : 0240-8910

\section{Référence électronique}

Astrid Nunn, « «Les Sidoniens à Baniyas ». Transeuphratène, 28 (2004), pp. 143-147. », Abstracta Iranica [En ligne], Volume 27 | 2006, document 93, mis en ligne le 02 janvier 2007, consulté le 25 septembre 2020. URL : http://journals.openedition.org/abstractairanica/5743 ; DOI : https://doi.org/10.4000/ abstractairanica.5743

Ce document a été généré automatiquement le 25 septembre 2020.

Tous droits réservés 


\section{«Les Sidoniens à Baniyas». Transeuphratène, 28 (2004), pp. 143-147.}

\section{Astrid Nunn}

Par trois fois la Bible se réfère à des Sidoniens qui n'habitent pas Sidon. Ces trois cas sont liés au Mont Hermon et à la grotte de Paneion située à son extrémité sud-ouest. La céramique a montré que cette grotte, important centre cultuel hellénistique, existait déjà à la fin de l'âge du Fer et à l'époque achéménide. Néanmoins on ne sait pas encore quand Sidon contrôlait exactement cette région.

\section{INDEX}

Thèmes : 3.2.1. Elam

\section{AUTEURS}

\section{ASTRID NUNN}

Université de Munich 